\title{
A STATISTICAL STUDY OF THE EFFECT OF EXCESSIVE FEE- DING OF CALCIUM AND PHOSPHORUS SUPPLEMENTS ON THE BLOOD CALCIUM AND PHOSPHORUS OF DAIRY COWS.
}

\author{
P. SAARINEN.
}

Agricultural Research Centre, Department of Animal Husbandry, Tikkurila, Finland.

Received 1. 8. 1950

A negative calcium and phosphorus balance generally is considered normal in dairy cows during the early part of the lactation period. High producing cows frequently have been noticed to be in negative calcium balance for the first 8 mo. postpartum and in negative phosphorus balance for the first 2 mo. postpartum, even when mineral supplements have been fed $(4,5)$. When calcium and phosphorus supplies are restricted, the blood calcium and phosphorus also vary markedly, and a very low intake finally results in lowered milk production $(3,6,7,9,21)$.

Added minerals along with the proper amount of vitamin D may help to shorten the period of negative mineral balance. The results, especially those obtained with growing bovines, indicate that the ability to assimilate calcium and phosphorus is limited (14). The inability of the cow to assimilate from her food sufficient inorganic constituents, especially calcium and phosphorus, is considered by some authors to be one of the possible limiting factors of high life time production $(12,18)$.

The experiments carried out by Huffman et al. (8) indicate that 10 to $12 \mathrm{~g}$. of phosphorus daily are sufficient for maintenance, normal growth and reproduction. These workers found that $17 \mathrm{~g}$. of phosphorus were sufficient for the average dairy cow which produces a moderate amount of milk. The addition of $0.75 \mathrm{~g}$. of phosphorus to the ration per pound of milk porduced was suffiecent for normal milk prodution.

Calcium requirements usually are considered to be of the same order or slightly higher than those of phosphorus. According to Meigs et al. (12) an abnormal ratio of calcium to phosphorus may interfere with phosphorus assimilation. BETHKE et al. (2) came to the conclusion that with rats the ratio of calcium to phosphorus is of greater significance in calcification than the concentration of these respective elements in the ration. 
A practical mineral feeding standard for a $1000-1 b$. dairy cow recommended by Morrison (13) is $10 \mathrm{~g}$. each of calcium and phosphorus per day for maintenance and a further addition of 1.0 and $0.75 \mathrm{~g}$. respectively, of calcium and phosphorus per pound of milk produced. An additional allowance of $13 \mathrm{~g}$ of calcium and $8 \mathrm{~g}$ of phosphorus per day is recommended for the last 2 to 3 mo. of pregnancy. Consequently, $60 \mathrm{~g}$. of calcium and $47.5 \mathrm{~g}$. of phopshorus would be adequate for a $1000-1 \mathrm{~b}$ cow producing $50 \mathrm{lb}$. of milk per day.

This standard, though adequate in favorable conditions, seems to be somewhat low in areas with meagre sunlight and a limited supply of vitamin $\mathrm{D}$. The standards recommended, for example, in some northern European countries $(1,10$, 15) are, in fact, somewhat higher than the standard given by Morrison. All these standards, however, are of the same magnitude.

During the last two decades practical dairymen in Finland frequently have been feeding calcium and phosphate supplements in large excess, asserting that it is conducive to maintaining high milk production and high fat test. As accurate data concerning this were lacking, a study was conducted on a number of herds in Finland in which calcium and phosphorus supplements were fed in excess and in which feed records were abailable.

\section{Experimental procedure.}

For this study, 16 large purebred Ayshire herds originally were chosen from among the farms constantly using high calcium and phosphorus feeding standards. Blood samples were drawn from 8 to 15 representative cows in each herd. Only one blood sample was taken from each cow, but in certain cases two sets of samples were collected from the same herd in 2 successive yr. These samples were taken during the latter part of the barn feeding period in the years 1936 and 1937.

The feeding consisted of 15 to $22 \mathrm{lb}$. of roughage (mainly clover- timothy hay and some straw), silage or roots and concentrate mixtures. In one case, fermented clover hult mash was used instead of silage. All the cows either were fed according to or slightly higher than the net energy standards of PoIJÄRvi (16).

The feed stuffs were weighed for the whole group and divided equally by sight, for each cow, except the concentrates, which were measured out for each cow from a quantity weighed for the group. The mineral supplements were mixed with the concentrates. The calcium was in the form of $\mathrm{CaCO}_{3}$, either as ground chalk or ground limestone, and phosphorus was in the form of $\mathrm{CaHPO}_{4}$.

The cows were milked from 1 to 2 hrs. before the blood samples were taken and after 3 hrs. they were milked again. The milk yields and fat tests were recorded for both the 3 -hr. and 24 -hr periods, but only the latter were used in this study. The measured weights of the cows (15, p. 441) also were recorded. Because of a slight variation in the size of the cows and because the feeding was not strictly individual, the feeding data have been used as such, instead of the amounts calculated in proportion to the live weight or to the maintenance requirements. Data from 274 cows have been used in this study. 
As the main part of the total calcium and most of the phosphorus were contained in the mineral supplement, their contents in the other feed stuffs were not analyzed separately. Standard values for each of these feedstuffs were used instead. The calcium and phosphorus values for the mineral supplements were taken from the state control laboratory certificates, provided with each batch of mineral supplement.

The blood minerals were determined on trichloracetic acid filtrates of whole blood. Inorganic phosphorus was determined by the earlier published modification (19) of the Kuttner et al. procedure. Calcium, sodium and potassium were determined from the same filtrates, using Lundegårdh,s spectrographic method (11). Copper was used in the filtrates as a quantitative indicator in addition to the standards. Blood chlorine was determined according to WHITEHORN's procedure (22).

The effect of four different factors on the calcium and inorganic phosphorus level of the blood, usually considered as effective in the assimilation of calcium and phosphorus, namely, the amounts of these minerals in feed, milk yield, stage of lactation and the $\mathrm{Ca} / \mathrm{P}$ ratio of the ration, have been investigated statistically. For this purpose, the coefficients of partial correlation have been calculated for each of these, assuming that blood calcium and inorganic phosphorus are variables dependent on the above mentioned independent variables. The method used was that of the least squares of the deviations.

\section{Results.}

The averages with their standard errors, the standard deviations and the extreme limits of variation for each variable studied, are presented in table 1 . It will be noticed that the blood calcium and phosphorus values show a variation that is fairly normal for whole blood. The average milk yield was about $45 \mathrm{lb}$. The stage of lactation, expressed as days in milk, represented the period of lactation when cows usually are in negative calcium balance. The 2 mo. period when cows usually are in a negative phosphorus balance, however, is represented to a smaller extent. Both the calcium and phosphorus in the ration exceeded the common standards. The lowest $\mathrm{Ca} / \mathrm{P}$

TABLE 1

The averages, standard errors, standard deviations and the range of variations in the material used.

\begin{tabular}{|c|c|c|c|c|}
\hline Variable & $\mathrm{n}$ & $\mathrm{M} \pm \mathrm{mM}$ & $\delta$ & Range \\
\hline Calcium in blood $(m g . / 100 \mathrm{ml}.) \quad \ldots \ldots \ldots \ldots$ & 274 & $6.52 \pm 0.062$ & 1.0297 & $4.01-10.62$ \\
\hline Inorganic phosphorus in blood $(\mathrm{mg} . / 100 \mathrm{ml}) .$. & 274 & $4.30 \pm 0.047$ & 0.7772 & $2.66-7.38$ \\
\hline Calcium in the ration $(g \cdot / d.) \quad \ldots \ldots \ldots \ldots \ldots$ & 274 & $160.44 \pm 5.98$ & 99.046 & $67-555$ \\
\hline Phosphorus int he ration $(g . / d.) \ldots \ldots \ldots \ldots$ & 274 & $93.14 \pm 1.70$ & 28.205 & $33-157$ \\
\hline Milk yield $(k g . / d.) \ldots \ldots \ldots \ldots \ldots \ldots \ldots$ & 274 & $20.34 \pm 0.24$ & 3.946 & $1.09-33.6$ \\
\hline Days in milk $\ldots \ldots \ldots \ldots \ldots \ldots \ldots \ldots$ & 274 & $68.61 \pm 2.71$ & 44.857 & $20-252$ \\
\hline $\mathrm{Ca} / \mathrm{P}$ ratio in the ration $\ldots \ldots \ldots \ldots \ldots$ & 274 & $2.07 \pm 0.054$ & 0.9002 & $1.07-3.91$ \\
\hline
\end{tabular}


The coefficients of partial correlation when the blood calcium $\left(x_{1}\right)$ was considered as the dependent variable and calcium in feed $\left(x_{2}\right)$, milk yield $\left(x_{3}\right)$, days in milk $\left(x_{4}\right)$ and the Ca/P ratio $\left(x_{5}\right)$ of the ration as independent variables, $(n=274)$.

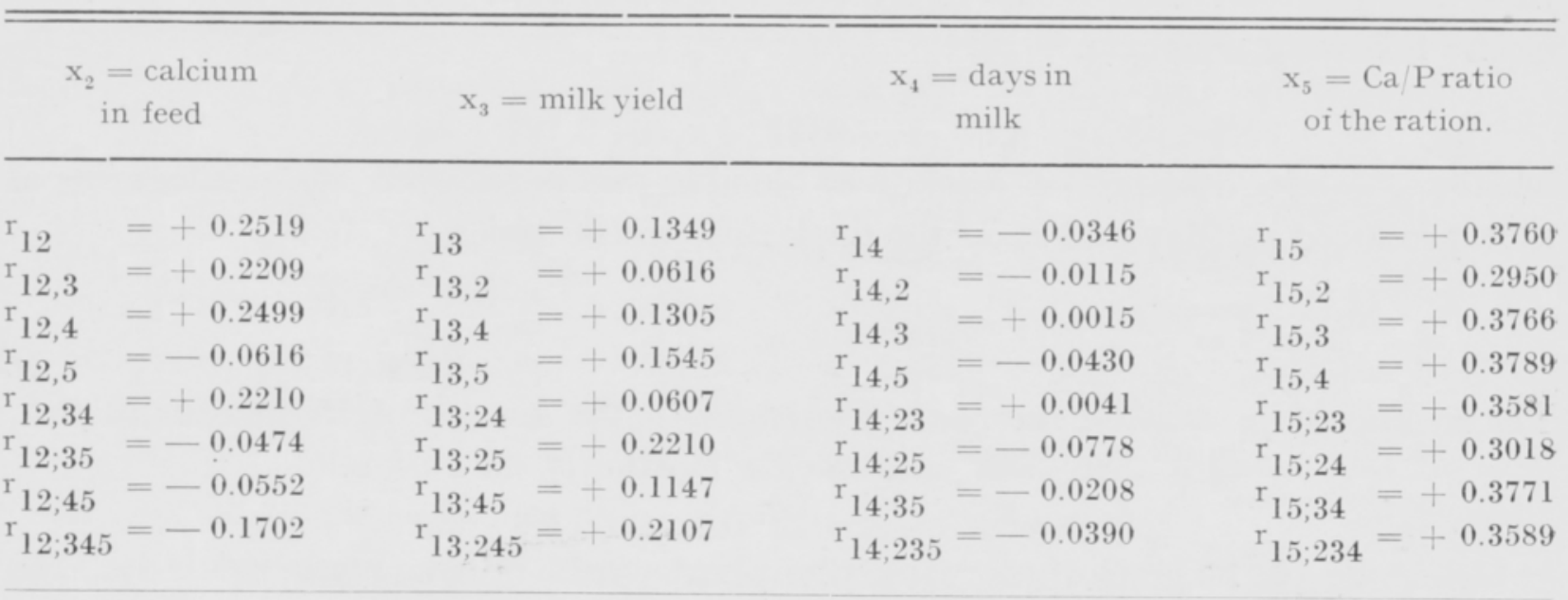

ratio in the ration was slightly lower than the amount that was considered as optimum according to the feeding standards, and extreme cases were selected in which the $\mathrm{Ca} / \mathrm{P}$ ratio exceeded the standards by almost four times.

According to the results presented by the earlier workers, it was expected that, under these circumstances, neither additional calcium nor phopshorus would show any distinct effect on the blood calcium and phosphorus levels, and that the high $\mathrm{Ca} / \mathrm{P}$ ratio possibly would have a negative effect on the blood phosphorus.

The relationship between blood calcium and the amount of calcium in feed, the amount of milk produced, the stage of lactation and the Ca/P ratio of the ration.

The statistical dependability of the blood calcium $\left(x_{1}\right)$ on four supposedly independent variables, e.g., calcium in feed $\left(x_{2}\right)$, milk yield $\left(x_{3}\right)$, days in milk $\left(\mathrm{x}_{4}\right)$ and the $\mathrm{Ca} / \mathrm{P}$ ratio in feed is presented in table 2 . It will be observed that the stage of lactation does not show any significant correlation in any combination and, hence, can be eliminated from the calculations. The coefficient of multiple correlation would then be, $r_{1(235)}=0.4321$. This relatively high value, however, is possibly still incidental because if the effect of the $\mathrm{Ca} / \mathrm{P}$ ratio $\left(x_{5}\right)$, which shows the highest correlation to $x_{1}$, is taken into consideration, then the effect of the actual calcium content in the ration $\left(x_{2}\right)$ is statistically insignificant, as will be seen from the coefficient $r_{12 ; 5}=-0.0616$ and $r_{12 ; 35}=-0.0474$. This result remained practically the same even when the actual amount of phosphorus was included in the calculation as an additional variable. This suggests that the $\mathrm{Ca} / \mathrm{P}$ ratio, rather than the actual amounts of these minerals in the ration, affected the blood calcium.

The two remaining variables $x_{3}$ and $x_{5}$ give a coefficient of multiple correlation $\mathrm{r}_{1(35)}=0.3966$ which, within the limits of experimental error, is the same as the 
coefficient obtained when all the variables were included. Hence, the practical result of this consideration appears to be that only two of the variables studied, namely, the amount of milk produced $\left(x_{3}\right)$ and the $\mathrm{Ca} / \mathrm{P}$ ratio $\left(x_{5}\right)$ showed any statistically significant effect on the calcium content of the blood. The effect of both of these was positive. This effect expressed as a linear function would take the form of the following equation:

$$
x_{1}=4.88+0.0373 \cdot x_{3}+0.427 \cdot x_{5}
$$

where $x_{1}=$ the amount of calcium in blood in $\mathrm{mg}$. per $100 \mathrm{ml} ., x_{3}=$ kilograms of milk produced per day and $x_{5}=$ the $\mathrm{Ca} / \mathrm{P}$ ratio in the ration.

The Relationships of blood inorganic phosphorus to the amount of phosphorus in feed, the milk yield, and the Ca/P ratio of the ration.

A study of the level of inorganic phosphorus in blood was made similarly. The stage of lactation did not show any significant effect on blood phosphorus. The 2-mo. period after parturition, when a negative phosphorus balance usually occurs and when the assimilation of phosphorus is inadequate, is, however, only partially represented in this set of observations. Hence, the results regarding the stage of lactation are excluded from the data presented in table 3 which show the statistical dependability of blood inorganic phosphorus $\left(x_{1}\right)$ on the amount of phosphorus in the ration $\left(x_{2}\right)$, the amount of milk produced $\left(x_{3}\right)$ and the $\mathrm{Ca} / \mathrm{P}$ ratio of the ration $\left(x_{4}\right)$.

According to the results presented in table 3, the blood inorganic phosphorus varies almost independently of the $\mathrm{Ca} / \mathrm{P}$ ratio in the ration. However, the actual amount of phosphorus in feed had a proportionally high positive influence on the blood phosphorus. If the effect of the feed phosphorus is taken into consideration, then the milk yield appeared to have a slight negative effect on the blood phosphorus level, as will be seen from the coefficients, $\mathrm{r}_{12,2}=-0.1447$ and $\mathrm{r}_{13 ; 24}=-0.1461$ The effect of milk yield on both blood calcium and phosphorus was of the same magnitude, but in the case of blood calcium it was positive and in the case of blood phosphorus, negative.

The coefficient of multiple correlation when all three variables are included is $r_{1(234)}=0.4963$, and when only feed phosphorus and milk yield are included, it remains practically the same, namely $\mathrm{r}_{1(23)}=0.4892$. Both are statistically significant.

The results presented here show that of the variables studies only two, the actual amount of phosphorus in feed and, to a lesser extent, the amount of milk produced, had any, significant effect on the level of inorganic phosphorus in the blood. No detrimental effect on the latter was observed due to the relatively high $\mathrm{Ca} / \mathrm{P}$ ratio of the ration.

The effect of phosphorus in the ration and of the milk yield on the level of blood inorganic phosphorus, expressed as a linear function of these, is given by the following equation: 
TABLE $3^{\circ}$

The coefficients of partial correlation when the blood inorganic phosphorus $\left(x_{1}\right)$ is considered as the dependent variable and phosphorus in feed $\left(x_{2}\right)$, milk yield $\left(x_{3}\right)$ and the Ca/P ratio of the ration $\left(x_{4}\right)$ as independen variable $(n=274)$.

$\begin{array}{ccc}\mathrm{X}_{2}=\text { phosphorus } & \mathrm{X}_{3}=\text { milk } \\ \text { in feed } & \text { yield } & \mathrm{X}_{4}=\mathrm{Ca} / \mathrm{P} \text { ratio of } \\ & \text { the ration }\end{array}$

\begin{tabular}{|c|c|c|c|c|}
\hline & $=+0.4723$ & & $=+0.0625$ & $=+0.0231$ \\
\hline${ }^{\mathrm{r}} 12,3$ & $=+0.4861$ & ${ }^{\mathrm{r}} 13,2$ & $=-0.1447$ & $=+0.0747$ \\
\hline 促 & $=+0.4766$ & ${ }^{\mathrm{r}} 13,4$ & $=+0.0630$ & $=+0.0246$ \\
\hline $12 ; 34$ & 0.4904 & ${ }^{\mathrm{r}} 13 ; 24=$ & $=-0.1461$ & $\mathrm{r}_{14 ; 23}=+0.0521$ \\
\hline
\end{tabular}

$$
x_{1}=3.59+0.0142 \cdot x_{2}-0.0304 \cdot x_{3}
$$

where $x_{1}=$ inorganic phosphorus in blood (mg. per $\left.100 \mathrm{ml}\right), x_{2}=$ phosphorus in the ration (g. per day) and $x_{3}=$ he amount of milk produced (kg. per day).

\section{Discussion.}

If the statistical correlations noticed in this study represent true physiological correlations, they indicare that the excessive feeding of phosphate supplements and a high $\mathrm{Ca} / \mathrm{P}$ ratio in the ration can be conducive to maintaining correspondingly a high phosphate and calcium level in the blood of high producing dairy cows. The slightly negative effect of milk yield on blood phosphorus and the slightly positive effect on blood calcium, observed in this study, possibly can be explained by an increased removal of blood phosphate by the mammary gland, followed by an accelerated mobilization of bone phosphates whereby calcium is mobilized in excess. If this latter is true, then it also is possible that the high $\mathrm{Ca} / \mathrm{P}$ ratio could similarly affect blood calcium through bone deposits, by retarding the absoroption of phosphorus from the intestinal tract and by increasing the mobilization of bone calcium simultaneously when phosphorus is removed from the bone. Statistically, the high $\mathrm{Ca} / \mathrm{P}$ Ratio did not, however, show any negative effect on the level of blood inorganic phosphorus. Hence, it appears possible that the positive effects of the excessive amounts of phosphorus and of the high $\mathrm{Ca} / \mathrm{P}$ ratio noticed in this study can both be real.

For an additional check, the $\mathrm{pH}$ of both arterial blood and feces were determined on 65 cows on different levels of calcium and phosphorus intake and on rations with widely varying $\mathrm{Ca} / \mathrm{P}$ ratios. The determinations were made electrometrically at body temperature using a glass electrode. The feces were taken directly from the rectum and the blood was drawn under oil from the coccygeal artery (20). The average blood $\mathrm{pH}$ was 7.503. Slight variations were observed which appeared to be indepen dent of the $\mathrm{Ca} / \mathrm{P}$ ratio of the ration. The average $\mathrm{pH}$ of the feces in different groups 
varied from 6.29 to 6.38 , but the total range observed $(6.04-6.69)$ was almost the same in each group.

However, when the total mineral composition of the blood was investigated, it was noticed that the blood always contained, on a chemical equivalent basis, more cations $\left(\mathrm{Na}^{+}, \mathrm{K}^{+}, \mathrm{Ca}^{++}\right)$than anions $\left(\mathrm{Cl}^{-}, \mathrm{PO}_{4}{ }^{--}\right)$. The esterified phosphates were included as anions. The excess of cations also was almost constantly higher than could be explained by the normal amount of bicarbonate alkali reserve in the blood. For an additional check, the alkali reserve also was determined separately on 75 blood samples using Van Slyke's manometric method (17). The results obtained showed that the bicarbonate alkali reserve was not high, averageing only 52.4 per cent $\mathrm{CO}_{2}$ by volume. On the equivalent basis, this was only about one half of the total amount of the excess of cations found in the blood. The amount of inorganic anions other than chlorides and phosphates was neglibigle. Hence, it was concluded that the other half of the alkali reserve in the blood was mainly in the form of organic salts and/or protein combinations. When investigated statistically, the total amount of the alkali reserve in the blood varied independently of the $\mathrm{Ca} / \mathrm{P}$ ratio of the ration. Simultaneously, the correlation between the $\mathrm{Ca} / \mathrm{P}$ ratio of the ration and the amount of the bicarbonate alkali reserve in the blood was negative $(\mathrm{r}=-0.4185 \pm 0.0953)$. This suggests that the high $\mathrm{Ca} / \mathrm{P}$ ratio of the feed, or possibly the excessive amount of calcium carbonate in the ration, had resulted in an increased fermentation in the rumen and a replacement of plasma bicarbonates by salts oi some organic acids. This also may have influenced indirectly the level of calcium in the blood and may be the explanation for the positive correlation between the $\mathrm{Ca} / \mathrm{P}$ ratio of the ration and the level of calcium in the blood noticed in this study.

Hence, it appears that this preliminary study has given a rather positive result regarding the possibilities of the positive effects asserted to be obtainable with an excessive feeding of calcium and phosphate supplements to high producing dairy cows. Except for the slight correlation between blood calcium and phosphous and milk yield, no other concusions can be drawn from the data presented above regarding the physiological effects of the changes in the mineral composition of blood on the milk and milk fat yield. These problems were investigated simultanneously but the results will be discussed in a later communication.

\section{Summary and conclusions.}

A statistical study of the effects of the feeding of large amounts of calcium and phosphorus supplements or the level of these minerals in the blood of dairy cows was made on the basis of 274 blood samples collected from 15 herds. The effects of four presumably independent variables, the actual amount of either calcium or phosphorus in the ration, milk yield, stage of lactation and the $\mathrm{Ca} / \mathrm{P}$ ratio of the ration, were investigated simultaneously.

When the level of calcium in the blood $\left(x_{1}\right)$ was considered as the dependent variable, it showed a possibly significant correlation only to two of the above men- 
tioned independent variables, e.g., to $\mathrm{Ca} / \mathrm{P}$ ratio $\left(x_{2}\right)$ and milk yield $\left(x_{3}\right)$. The coefficients of partial correlation obtained were $r_{12,3}=+0.3766$ and $r_{13,2}=+$ 0.1545 and that of multiple correlation $\mathrm{r}_{1(23)}=0.3966$. These correlations can be expressed quantitatively with the following equation: $x_{1}=4.88+0.427 . x_{2}$ $+0.0373 \cdot x_{3}$, where $x_{1}=$ the amount of calcium in blood in $\mathrm{mg}$. per $100 \mathrm{ml}$, $x_{2}=$ the $\mathrm{Ca} / \mathrm{P}$ ratio of the ration and $x_{3}=$ kilograms of milk produced per day.

When the effect on the level of inorganic phosphorus in $\mathrm{mg}$. per $100 \mathrm{ml}$. of blood $\left(x_{1}\right)$ was investigated similarly, again only two of the variables studied, e.g., the actual amount of phosphorus (g. per day) in the ration $\left(x_{2}\right)$ and the milk yield $\left(x_{3}\right)$ appeared to be effective. The coefficients of partial and multiple correlations obtained were $\mathrm{r}_{12,3}=+0.4861, \mathrm{r}_{13,2}=-0.1447$ and $\mathrm{r}_{1(23)}=0.4892$. This effect, expressed as a linear function, is given by the following equation: $x_{1}=3.59+$ $+0.0142 \cdot x_{2}-0.0304 \cdot \mathrm{x}_{3}$.

When the cations $\mathrm{Na}^{+}, \mathrm{K}^{+}$, and $\mathrm{Ca}^{++}$, and the anions $\mathrm{Cl}^{-}$and $\mathrm{HPO}_{4}^{--}$were determined separately in the blood, the total amount of cations expressed in chemical equivalents exceeded the total equivalent amount of inorganic anions to an amount that was about twice the equivalent amount of the bicarbonate alkali resrve of the blood. The total cation excess varied independenly of the $\mathrm{Ca} / \mathrm{P}$ ratio of the ration, but the latter showed a negative correlation to the bicarbonate alkali reserve, probably due to an increasing amount of organic acids in the blood. No effect on the $\mathrm{pH}$ of either blood of feces was noticed. It is concluded that an excessive amount of phosphate may be conducive to maintaining a high blood inorganic phosphate level. Similarly, a high $\mathrm{Ca} / \mathrm{P}$ ratio of the ration or an excessive amount of calcium carbonate in the feed, along with proper rumen fermentation, may be conducive to maintaining a high calcium content in the blood of high producing dairy cows.

\section{Acknowledgements.}

The author wished to extend his sincere appreciation to I. PoIJärvi, Head of the Department of Animal Husbandry, for making the necessary arrangements to conduct this study at the Agricultural Research Centre of Finland; to L. LeHtoRANTA for photographing the spectra; to E. M. LIsTo for her assistance in determining the blood inorganic phosphorus and to J. C. SirAw for assisting in the writing of the manuscript.

\section{REFERENCES.}

(1) Axelsson, J. 1943. Nötkreaturens Utfodring och Skötsel, Del 1, p. 1-386 Nordisk Rotogravyrs Handböcker för Jordbrukare. Stockholm.

(2) Bethke, R. M., Kick, H. C. and Wilder, H. M. 1932. Relation of the Calcium-phosphorus Ratio to Calcification. Ohio Agr. Expt. Sta., Bull., 446. 
(3) Eckles, C. H., Gullickson, T. W. and Palmer, L. S. 1932 Phosphorus Deficiency in the Rations of Cattle. Minn. Agr. Expt. Sta., Tech. Bull., 91, p. 1-117.

(4) Ellenberger, H. B., Newlander, J. A. and Jones, C. H. 1931. Calcium and Phosphorus Requirements of Dairy Cows. I. Weekly Balances through Lactation and Gestation Periods. Vt. Agr. Exps. Sta., Bull., 331, p. 1-27.

(5) Forbes, E. B., Black, A., Braman, W. W., Frear, D., Kahlenberg, O., McClure, F. J., Swift, R. W., and Voris, LeRoy. 1935. The Mineral Requirements of Milk Production; the Annual Cycle of Mineral and Nitrogen Metabolism of the Milk Cow, as Affected by Alfalfa Hay, Timothy Hay, Bone Flour, and Ground Limestone. Pa. Agr. Expt. Sta., Bull., 319 , p. $1-152$.

(6) Greaves, J. E., Maynard, E. J., and Reeder, Wendel. Influence of Calcium Phosphorus Intake on Bovine Blood. J. Agr. Research, 48, 0. 1033-1041.

(7) Groenewald, J. W. 1935 - The Influence of Rations Low in Certain Minerals on the Compositiion of the Blood and Milk of Cows, and on the Blood of their Progeny. Onderstepoort J. Vet. Sci. Animal Ind., 4, p. $93-165$.

(8) Huffman, C. F., Duncan, C. W., Robinson, C. S. and Lamb, L. W. 1933. Phosphorus Requirement of Dairy Cattle when Alfalfa Furnished the Principal Source of Protein. Mich. Agr. Expt. Sta., Tech. Bull., 134, p. 1-75.

(9) Johnson, S. R. 1939. The Level of Inorganic Phosphorus in the Blood of Dairy Cattle. J. Nutrition, 17, p. $15-21$.

(10) LARsson, S. 1945. Husdjurslära. Del II. Husdjurens Utfordring och Vård. Sjunde omarbetade upplagan. Stockholm, Lantbruksförbundets Tidskriftsaktiebolag.

(11) LundegÅrdh, Henrik. 1929. Die quantitative Spektralanalyse der Elemente und ihre Anwendung auf biologische, agriculturchemische und mineralogische Aufgaben. Gustav Fischer, Jena.

(12) Meigs, E. B., Turner, W. A., Harding, T. S., Hartman, A. M., and Grant, F. M. 1926. Calcium and Phosphorus Metabolism in Dairy Cows. J. Agr. Research, 32, p. 833-850.

(13) Morrison, Frank B. Feeeds and Feeding. 1948. A Handbook for the Student and Stockman. 21 st ed., Ithaca, N. Y., The Morrison Publishing Co.

(14) Отто, J. S. 1938. The Assimilation of Calcium and Phosphorus by the Growing Bovine. Onderstepoort J. Vet Sci. Animal Ind., 10, p. 281-364.

(15) Paloheimo, L. 1947 - Kotieläinhoidon perusteita. Toinen perinpohjin uusittu painos teoksesta Kotieläinoppi, p. 1-604. Jyväskylä, K. J. Gummerus Oy.

(16) PoIJÄRvi, I. 1925. Suomalaisen lypsykarjan ravinnontarve käytännöllisten ruokintakokeiden valossa. Maatalouskoelaitoksen tieteellisiä julkaisuja, 26, p. 1-137.

(17) Rona, P. 1929. Praktikum der physiologischen Chemie. II. Teil, Berlin, Paul Parey.

(18) Rose, R. A. 1912. A Study of the Metabolism and Physiological Effects of Certain Phosphorus Compounds with Milk Cows. II. N. Y. Agr. Expt. Sta. (Geneva). Tech. Bull., 20, p. 1-32.

(19) SaArinen, P. 1938. Fosforihapon määräämisestä veressä. Ref. Über die Bestimmung der Phosphorsäure im Blut. J. Sci. Agr. Soc. Finland, 10, p. 128-139.

(20) —- 1938. Einfaches Verfahren zur Gewinnung von Arterienblutproben beim Rindvieh. J. Sci. Agr. Soc. Finland, 10, p. $140-146$.

(21) Van Landingham, A. H. Henderson, H. O. and Bowling, G. A. 1942. Studies on the Chemical Composition of the Blood of Dairy Cattle. III. The Normal Concentration of Inorganic Phosphorus in the Whole Blood of Dairy Cattle and Factors Affecting it. J. Dairy Sci., 25 , p. $537-548$.

(22) Whitehorn, J. C. 1921. A System of Blood Analysis. Supplement II. Simplified Method of the Determination of Chlorides in Blood or Plasma. J. Biol. Chem., 45, p. 449-460. 
S E L O S T U S.

TILASTOLLINEN TUTKIMUS RUNSAAN KALSIUM- JA FOSFORIRUOKINNAN VAIKUTUKSESTA LEHMÄN VEREN KALSIUM- JA FOSFORIPITOISUUTEEN.

P. SAARINEN.

Maatalouskoelaitoksen kotieläinhoito-osasto, Tikkurila.

Edellä selostettu alustava tutkimus selvittelee runsaan kivennäisruokinnan mahdollisia vaikutuksia lehmän veren kalsium- ja fosforipitoisuuteen. Tutkimus on tilastollınen ja perustuu viidestätoista karjasta kerättyyn 274 verinäytteeseen. Laskelmissa on neljää yleisesti vaikuttaviksi otaksuttua tekijää, nimittäin kalsiumin tai fosforin määrää rehussa, tuotetun maidon määrää, tuotantovaihetta ja Ca/Psuhdetta, käsitelty riippumattomina muuttujina ja veren Ca- ja P-pitoisuutta näiden funktiona.

Kun happoon liukenevan kalsiumin määrää veressä $\left(x_{1}\right)$ käsiteltiin tutkittavina olevien tekijöiden funktiona, niin se näytti merkittävissä määrin riippuvan ainoastaan kahdesta tekijästä, Ca/P-suhteesta rehussa $\left(x_{2}\right)$ ja samanaikaisesti tuotetun maidon määrästä $\left(x_{3}\right)$. Tutkimuksessa todetut osittaiskorrelatiokertoimet olivat $\mathrm{r}_{12,3}=+0.3766$ ja $\mathrm{r}_{13,2}=+0.1545$ sekä kerrannaiskorrelatiokerroin $\mathrm{r}_{1}\left({ }_{23}\right)=0.3966$. Lineaarifunktio, jonka arvot mahdollisimman hyvin liittyvät vastaaviin tilaston mukaisiin arvoihin, voidaan ilmaista yhtälöllä : $x_{1}=4.88+0.427 \cdot x_{2}+0.0373 \cdot x_{3}$, jossa yhtälössä $x_{1}=$ veren kalsiumpitoisuus ilmaistuna milligrammoissa $100 \mathrm{ml}$ :aa kohden, $x_{2}=$ painomääräinen Ca/Psuhde rehussa ja $x_{3}=$ vuorokaudessa tuotettu maitomäärä ilmaistuna kiloissa.

Happoon liukenevan fosforin määrä veressä näytti myöskin riippuvan pääasiallisesti vain kahdesta tekijästä, nimittäin fosforin määrästä $(\mathrm{g} / \mathrm{pv})$ rehuannoksessa $\left(x_{2}\right)$ ja tuotetun maidon määrästä $\left(x_{3}\right)$. Todetut osittais- ja kerrannaiskkorrelatiokertoimet olivat: $\mathrm{r}_{12,3}=+0.4861, \mathrm{r}_{13,2}=-0.1447$ ja $\mathrm{r}_{1}\left({ }_{23}\right)=0.4892$. Veren fosforipitoisuuden rippuvaisuus edellämainitusta kahdesta muusta suureesta voidaan ilmaista yhtälöllä: $x_{1}=3.59+0.0142 \cdot x_{2}-0.0304 \cdot x_{3}$.

Kun kationit $\mathrm{Na}^{+}, \mathrm{K}^{+}$ja $\mathrm{Ca}^{++}$sekä anionit $\mathrm{Cl}^{-}$ja $\mathrm{HPO}_{4}{ }^{-}$määrättiin erikseen veren trikloorietikkahappouutteesta, niin voitiin todeta, että kationien ekvivalenttimäärä oli huomattavasti suurempi kuin edellämainittujen epäorgaanisten anionien ekvivalenttimäärä. Laskemalla määrätty kationien kokonaisylimäärä oli myös suunnilleen kaksi kertaa suurempi kuin veressä todettu bikarbonaattialkalireservien määrä. Kationien kokonaisylimäärä vaihteli riippumatta $\mathrm{Ca} / \mathrm{P}$-suhteesta rehussa, mutta viimeksimaınitun ja bikarbonaattialkalireservien määrän välillä voitiin erikseen todeta negatiivinen vuorosuhde $(\mathrm{r}=-0.4185+0.0953)$. Bikarbonaattien määrän vähenemisen on tässä tutkimuksessa otaksuttu mahdollisesti johtuneen orgaanisten happojen määrän lisääntymisestä veressä. Runsaan kivänneisruokinnan ei havaittu vaikuttavan veren tai lannan pH-arvoihin.

Edellä esitetyn perusteella näyttää mahdolliselta, että MorRisovin (13) lypsykarjalle suosittelemia kivennäisnormeja runsaammatkin fosfaattimäärät voivat vielä edistää veren fosfaattimäärän pysymistä korkealla tasolla erityisesti runsaan maidontuotannon vaiheessa. Toisaalta taas korkeakin $\mathrm{Ca} / \mathrm{P}$-suhde rehussa (2-4) taikka runsas kalsiumkarbonaattiruokinta yhdessä suotuisan pötsikäymisen kanssa näyttää voivan edistää lehmän veren kalsiumpitoisuuden pysyttämistä korkeana runsaan maidontuotannon vaiheessa. 